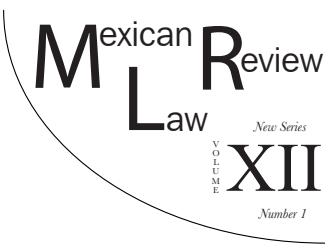

\title{
STRUCTURAL TRANSFORMATIONS OF POLITICAL RIGHTS: THE MEXICAN GASE
}

\author{
Carlos Soriano Cienfuegos*
}

\begin{abstract}
This note supports the hypothesis that democratization and openness to international human rights law in Mexico brought about a structural change in its constitutional principles. This was mainly the result of substantially transforming the meaning - and especially the scope - legally given to political rights. The change from prerogatives to rights is not only a matter of nomenclature, but also a 180-degree shift, at both practical and epistemological levels. In addition to this, the project to establish a Ius Constitutionale Commune in the region, based on human rights standards, has been an equally important change as it has placed the human person at the heart of the matter.
\end{abstract}

Keywords: Democratization; Political Rights; Ius Commune.

RESUMEN: En esta nota se sostiene la hipótesis de que la democratización y la apertura al derecho internacional de los derechos humanos, en México, trajo consigo un cambio en las instituciones constitucionales que se puede calificar de estructural. Esto es asi porque el significado -y sobre todo los alcances que juridicamente se daban a los derechos políticos antes y después - se transformó sustancialmente. Lo anterior, significa que el cambio de prerrogativas a derechos no es solo una cuestión de nomenclatura, sino que configura un giro de 180 grados, tanto a nivel práctico como epistemológico. Además, el proyecto de establecimiento de un Ius Constitutionale Commune en la región, a través de las normas en materia de derechos humanos, ha significado un cambio de igual trascendencia que ha puesto a la persona humana en el centro.

Palabras Glave: Democratización; Derechos políticos; Ius Commune.

* Associate professor, Universidad Panamericana and professor at the Instituto Tecnológico Autónomo de México. PhD. in Law at the Universidad Panamericana, master on Law at the University of Rome. Visiting scholar at the Lodwig-Maximilian University. Director of the Electoral Judicial School at the Electoral Tribunal of the Federal Judicature. Email: carlos.so riano@te.gob.mx. 
Esta revista forma parte del acervo de la Biblioteca Jurídica Virtual del Instituto de Investigaciones Jurídicas de la UNAM

\section{Table of Contents}

I. INTRODUCTION

II. The Transformation of the State: When the Power

is RATiOnAL

III. The Integration Project Focused on Human Rights: The Ius Constitutionale Commune for Latin America ............................. 173

IV. Political Rights ............................................................... 178

1. A Conceptual Change: Prerogatives and Rights ...................... 178

2. A Specific Reference to the Right to Vote ............................... 181

3. A Specific Reference to the Right to Hold Public Office .......... 181

V. A Tentative Conclusion: Belonging to Multiple Normative Spaces and the Person’s Gentrality

\section{INTRODUCTION}

Undoubtedly, one of the main pillars of Mexican authoritarianism was its medium-intensity control over democratic participation processes. The best example of this is that although elections were held regularly, votes were highly concentrated. Therefore, the Mexican electoral system was seen as belonging to the hegemonic party.

The shift towards democracy has undergone changes in various institutions one of them being political rights. This note argues that the structural transformations that both political power and the State have undergone have conceptually modified the normative meaning of political rights. This path was marked by the change in the conceptual paradigm: from prerogatives to rights and then to the recognition of a new form of assimilation through international human rights law.

The last of these great transformations is represented by the Ius Constitutionale project for Latin America, which intrinsically implies two things: 1) belonging to multiple normative spaces and 2) the centrality of the human person.

\section{The Transformation of the State: \\ When the Power is Rational}

By abandoning the organic idea of the ancient world, academic thought began to present the modern State as an artifact; that is, as an artificial work, not as a spontaneous product of human nature, but rather as a rational cre- 
ation resulting from the voluntary decision to live in society. In other words, it means to leave the State of a pre-contractual nature. ${ }^{1}$

Based on this premise and on contemporary doctrine, the basic models that summarize the explanations about the modern State can be alternatively condensed as: 1) the approach to the rationalization of the juridical-political institutions -which is saying, the system of Law and the State itself; 2) the value given to the unity imposed by the modern political organization -associated with sovereignty and the consequent rise above medieval pluralism; and 3) finally the balance of powers -whose version is not the mechanistic roots of modern thought are hidden. ${ }^{2}$ Naturally, the identification and separation of these models ${ }^{3}$ is only possible in theory as the primacy or exclusivity of any of them can be verified in scholarly works, but very rarely in the facts themselves.

The decades of transition between the nineteenth and twentieth centuries, concerned about the crisis of the liberal State, brought about a myriad of problems related to a wide variety of aspects, one of which was the issues derived from the constitutionalization of parties and unions. ${ }^{4}$ It was feared that this constitutionalization might conceal a form of regression towards estates; that is, an element contrary to political unity, which had become a fundamental feature of modern State organization. Moreover, controversies came about by increased bureaucracy towards another of the bastions of modernity, namely, the balance between authority and individuals. ${ }^{5}$ Hence, the balance was presumably compromised and damaged because of unsuspected growth. Furthermore, there was the theoretical concern of narrowing the gap between the public and the private spheres, also reputed as modern, because

\footnotetext{
1 José Antonio Maravall, Estado Moderno y Mentalidad Social, Siglos XV a XVII 50 (Alianza 1986).

2 "The triumph of the modern mentality has been the triumphant emergence of a form of thought that only considers the 'matter' always the same ... shaped by forms that become, in fact, accidental in the only law of the movement of matter. This mentality was underlying Descartes, Galileo and Newton, either as a necessary metaphysical postulate, or as a working hypothesis in Physics, and ended up shaping all modern-contemporary culture": FRANCISCO Carpintero, Historia breve del derecho natural 244 (2000).

343 Maurizio Fioravanti, Stato (Storia), in Enciclopedia del Diritto (Giuffrè 1990).

4 On the legalization and constitutionalization of political parties in the Latin American context, see Bernardino Esparza Martínez, Partidos políticos. Un paso de su formación POLÍTICA Y JURÍDICA 50 (Editorial Porrúa, 2005). With regard to the relevance of trade unionism for the definition of institutions, see AMARO DEL RosAL, Los CONGRESOS OBREROS INTERNACIONALES EN EL SIGLO XIX. DE LA JOVEN Europa A LA SEGUNDA INTERnACiOnAL (Editorial Grijalbo 1958).

5 "Modern techniques have made possible a new intensity of government control, and this possibility has been exploited very fully in totalitarian States. It may be that under the stress of war, or the fear of war, or as a result of totalitarian conquest, the parts of the world where some degree of individual liberty survives may grow fewer, and even in them liberty may become more and more restricted.": Bertrand Russell, Autoridad e individuo 42 (Fondo de Cultura Económica 1995).
} 
of the activity of public administration in terms of dealing with individuals through the figure of the contract. ${ }^{6}$

Because of this historical scenario, the models of the past century traditionally handed down over the years, have been shaped in a problematic climate. They are not exempt from answers, and follow the desire to point at safe paths of political modernization based on prescriptive content. This is to offer criteria that allow to identify everything that could move contemporary society away from the paradigms of modernity, and simultaneously serve as guidelines for action.

Nowadays, the prescriptivism orientation of the models still exists, although it no longer possesses the strength it had at the beginning of the 20th century. This tendency is reflected in the attitude of case law to consider the current conceptual reality during a period of crisis, precisely because of the lack of coincidence between facts and theoretical models. The previous or older paradigm, as Claus Offe describes it, has remained valid and effective until the crisis of the seventies. While the agents or 'Subjects of the 'old paradigm' were practically the only institutions (juridical-political), government, parliament, parties -although after them they operated economic corporations and unions more or less integrated organizationally in the system-; the 'actors' of the 'new paradigm' were fundamentally, in their strictest formulations, the new social movements."7

However, rather than talking about the crisis of the State institutions themselves, the prevailing perspective gravitates towards the intelligence of the crisis of the model. In other words, it does not seem plausible, for example, to deny the activity of governing bodies all rationality because it does not adapt to the formal elements defining the modern bureaucratic State as pointed out by Weber. Nor it is reasonable to affirm the dissolution of the modern political organization based on broad European pluralist structures, without relating it to the model that focuses its explanation of modernity on the annihilation of the particularisms in medieval society.

This crisis of theoretical models justifies the demand for their review. Consequently, it is only possible to postulate the extinction of the thought state and not of the lived reality. In the words of a contemporary scholar, the State that is dissipating is the imaginary one, and not the one that emerged at the end of the Middle Ages. This model explains the transformation of the paradigmatic. ${ }^{8}$ This thesis is based on the inadequacy of interpretive schemes to explain the contemporary legal-political reality, both on the functional level of a dynamic civil society and State, and the structural definition of institutions.

\footnotetext{
6 Fioravanti, supra, at 710 .

7 Elías Díaz, El Nuevo Contrato Social: Instituciones Políticas $Y$ Movimientos Sociales, in Historia, Lenguaje, sociedad. HOMenaje a Emilio Lledó 363 (Editorial Crítica 1989).

8 Pietro Costa, lo Stato Immaginario. Metafore e Paradigmi Nella Cultura Giuridica Italiana Fra Ottocento E Novecento (Giuffrè 1986).
} 
The affirmation that actual historical content coincides with its theoretical systems constitutes the very essence of historiography. As a methodology applicable to legal concepts, it leads science to rethink, in both the public and private spheres, the conceptual paradigms that have been used to interpret and explain matters inherent to them, verifiable data on dogmatic abstraction being preferred today, characterizing this time precisely because of their rejection of excessively ambitious rationalisms, whose limits have already been sufficiently criticized although without incurring in an apology for the irrational, as evidenced by the fact that the notion of a system is still prevalent in more restricted sectors of jurisprudence, of, even with the elementary variants that this epistemological itinerary has supposed.

From the examination of the paradigms that serve as a theoretical explanation of modern political institutions, it may be noted that the crisis of the welfare State does not necessarily lead to the dismissal of all the elements that characterize it, especially because there is a non-identification between the models and the values that the models strive to embody. This disorientation should not be interpreted unfailingly in terms of the exclusive crisis of doctrinal schemes because it is also an issue of " precisely a crisis of legitimation; that is, of cultural and social values, of the concept of the world' with a significant internal philosophical debate (analytical, dialectic, postmodern, etc.)."9

All this makes it possible to understand the historicity of political institutions. Indeed, the need to understand their transformations in order to correctly appraise their operation and functions is necessary to be in a position to determine the possibilities of studying political-electoral rights under the current system - in particular those referred to as the active and passive vote, traditionally designated ius suffragii and ius honorum. Therefore, the results of this analysis will identify the features of a complex and problematic reality, like that of contemporary State organization in Latin America, whose design has its roots in a deeper and more distant time, although structurally modern, and which presents as the heir of a long tradition that finds its original sources in Roman legal thought.

\section{The Integration Project Focused \\ on Human Rights: The Ius Constitutionale Commune FOR LATIN AMERICA}

Among the various normative designs of the right to vote, in both its active and passive aspects, it is possible to identify contextual characteristics in Latin America that have given rise to a minute analysis from the perspective of legal doctrine. Such characteristics can be framed into two processes that have been developed in different, albeit overlapping, time periods, namely, politi-

\footnotetext{
9 Díaz, supra, at 363.
} 
cal transitions, on the one hand, and State reform processes, on the other. This finds its raison d'etre in which the debate on the reform of the State has usually been aimed at guiding the democratic transition or consolidating the democratic political regime that has just been established. ${ }^{10}$

The Latin American region - like that of Eastern Europe - has provided sufficient empirical evidence on political changes towards democracy for authors like O'Donell and Schmitter who affirmed that a process of political liberalization, centered on the maximization of political rights and prerogatives, has become a reality. Moreover, according to these authors, it has involved the establishment of a principle of citizenship, which, in turn, has resulted in a transformation of the relations between public power and individuals ${ }^{11}$ while political freedoms have been presented as the touchstone of the electoral system.

Over time, and entering into the debate on democratic transitions or State reforms, globalization has modified several existing classical conceptions, particularly the notion of sovereignty, and therefore the sources of human rights, among which are the political rights.

A process of global transformation gained momentum in several fields: as occurred in the case of State reform. In addition to having the purpose of modifying political institutions, globalization was intended to introduce changes to the justice system, and to legal systems in general, but it did not stop there; the transformations now included - perhaps incidentally - a different way of thinking about public law. ${ }^{12}$

When describing this phenomenon from a legal perspective, it can be affirmed that with such processes, the classic elements of the State (government, population, laws, territory) do not disappear. The concept of these elements are profiled differently because of a new demand for sharing the responsibilities of security and democratic self-determination, and by creating a kind of interpretive pluralism with weak hierarchical positions, parallel to the exercise of authority. ${ }^{13}$ For this reason it has been pointed out that there are currently 'constitutional sites' in the various legal systems that are immersed in processes of public authority because of their essence. ${ }^{14}$

10 An interesting work is: José María Serna de la Garza, La Reforma del Estado en América Latina: Los casos de Brasil, Argentina y México, México (UNAM 1998) To document the centrality of electoral reform processes in the process of democratic change, see LA mecánica del cambio político en México, José Woldenberg et al. (Cal y Arena, 2006).

11 Guillermo O’donell \& Philippe Schmitter, Transiciones desde un gobierno autoRITARIO 21-26 (Paidós 1988).

12 In the case of Mexico, the objective of reforming the organs for the administration of justice was presented as a theme on the agenda to update the constitutional text; see JAIME Cárdenas Gracia, Una constitución para la democracia. Propuestas para un nuevo orden CONSTITUCIONAL 159 (UNAM 2000).

13 José María Serna de la Garza, Soberanía y apertura del Estado: una perspectiva mexicana, in Soberanía y Estado Abierto en América Latina y Europa 57 (UNAM 2014).

14 Id. Impacto e implicaciones constitucionales de la globalización en el sistema jurídico mexicano, Serna also uses the term 'legal spheres of a constitutional nature'. 
In other words, gradual adherence to human rights regimes has implied a process of constitutionalization in the region, which is certainly not centered on the concept of national sovereignty -in its various meanings,${ }^{15}$ but more properly on the basic notion of constitutionalism as a political idea. Moreover, it functions as the guiding axis of the various forms of government; that is, the constitution as a guarantee of rights, reaching beyond the various forms and specificities that shape such historical documents.

Thus, in an attempt to describe and explain these diverse processes, doctrine has spoken of regional constitutionalism, inter-American constitutionalism, acquis conventionnel and ius constitutionale commune ${ }^{16}$ to refer to a nucleus or core that can be considered constitutional, given its protective vocation derived from human rights. The inter-American ius constitutionale also bears the imprint of regional jurisdiction based on the Pact of San José, which offers another aspect for the composition of its object: dialogue among judges who have compiled the case law they have issued. ${ }^{17}$

From the point of view of Von Bogdandy, ${ }^{18}$ the ius constitutionale constitutes a political, legal and cultural project that, due to its inquisitive and challenging nature, poses great challenges to the science of public law. In this context, Serna proposes a definition of the research agenda that legal science now faces: it is a cross-cutting agenda that uses different approaches, methods, and even branches of legal knowledge, and proposes questions to the general theory of law, the field of comparative law, constitutional theory and, particularly, the history of law.

While comparative law requires the contribution and definition of concepts related to the so-called coexistence clauses of various legal regimes, like those used in federal systems, the theory of law calls for concepts that do not correlate the different rules of a system hierarchically.

15 Bogdandy says this as follows: "...without a doubt, the principle of sovereignty continues to have great importance, both in the law of the State and in international law, as well as in the theory of legitimacy. However, following a series of contemporary changes, the structure of public power can no longer be based on this principle alone. Openness and globalization undermine the famous premise of the classical principle of sovereignty according to which states are independent communities. With an image, Eyal Benvenisti clearly describes this paradigm shift: the old sovereignty resembled property over an isolated village on a large piece of land, while the new sovereignty resembles property over an apartment in a building with two hundred units": "Ius constitutionale commune latinoamericanum. Una aclaración conceptual", in Ius Constitutionale Commune en América Latina. Rasgos, potencialidades y desafíos 6 (UNAM 2014).

16 Mariela Morales Antoniazzi, El nuevo paradigma de los órdenes constitucionales, in SoberANía y Estado Abierto 269.

17 Id. at 271.

18 Diego Valadés \& Luis Raúl GonzÁlez PéRez, Ius constitutionale commune latinoamericanum. Una aclaración conceptual desde una perspectiva europea, in El Constitucionalismo Contemporáneo. Homenaje a Jorge Carpizo 44 (UNAM 2013). 
On this point, it should be recalled that, in perfect coherence with Kantian theses, it was Kelsen who mainly developed the most elaborate and complete concept of positive legal system. According to Kelsen's thesis, the law is an order that constitutes a system insofar as the validity of any norm can refer to a single source as its ultimate foundation. ${ }^{19}$ This original source establishes harmony among the plurality of provisions. In other words, law is systematic, not by logical relationship between norms, but by the delegation of its validity. In this way, the relationship between norms are not external, but link their validity with each other since the foundation of a legal proposal is the norm or norms that regulate its or their creation.

In this sense, any rule can prove, or not, its validity to the extent that it was created in accordance with certain directives established by a first authority. Now, it is necessary to establish the hypothesis of a statement declaring that the normative creation of that first legislator is valid: the rule that formulates the hypothesis of validity of these first acts is the founding norm of any positive law.

Therefore, we can speak of 'authority' because the relation/ of the validity of the provisions is equivalent to the power granted to produce them, based on the legislative branch and its legislative faculties. In other words, if there is a hierarchical order between norms, it is because a social organization with an unequal distribution of power is assumed. Therefore, the relationship between norms is not purely logical but expresses a structural relationship between the bodies empowered to create them. In this way, the system can be traced back to its last source.

On the other hand, the validity of legislative acts rests on a foundational norm of a gnoseological nature. In fact, it is a theoretical supposition, an a priori determination of scientific knowledge, of a principle. Then, the hypothetical norm is not a true norm, but a criterion for delimiting a positive legal order. It is the basic thesis of attribution of validity to the acts of the first legislator. Thus, the hypothetical norm of a positive law is an assertion of the science of law; that is, a theoretical assumption of knowledge and is obviously not a historical norm.

In synthesis, according to the Kelsenian school of thought, a system constitutes an interdependence of elements, an ideal set of factors in which the value of each element is not understood alone, but in function of the counter-value of the others: Law as order - the legal order - is a system of legal norms. A plurality of norms constitutes a unit, a system, an order. Its validity can refer to a single norm as the foundation of this validity. This fundamental norm constitutes, as a last source, cohesion of the plurality of all the laws that constitute an order. And if a provision belongs to a certain order, it is because its validity can be found in its fundamental norm. ${ }^{20}$

\footnotetext{
19 Hans Kelsen, Teoría Pura del derecho (Ed. Porrúa 1995).

20 La teoría pura del derecho. Método y conceptos fundamentales 47 Revista de Derecho Privado (1933).
} 
However, this concept is insufficient to explain the work of the contemporary legal operator, whose activity is no longer limited to a formal and axiomatic analysis of the rules, but, on the contrary, preponderantly covers all issues of content, semantics and meanings of the normative propositions to interpret them as best as possible; that is, according to the basic tenets of order. "Beyond logical discourse, whose meaning and scope may still, perhaps, remain in the field of natural and formal sciences, announces and shapes the broadest knowledge, that is understanding, the proper understanding of interpretation... Hence the new hermeneutics, as one of the most original and beneficial elements of contemporary German thought."21

Hence, this new vision of public law posits the use of categories of constitutional theory that harmonize the incorporation of international legal regimes. Finally, the history of law uses past experiences of the subsistence of various normative systems in the same geographical area.

On this last point, Serna ${ }^{22}$ specifically mentions the case of the coexistence of the so-called ius proprium and the ius commune on the Europe of the Late Middle Ages, although he omits a fundamental difference in new international law, this is the volitional element, as well as forgetting to refer to the original scheme, taken from the Romanist tradition by the commentators: ${ }^{23}$

Omnes populi, qui legibus et moribus reguntur, partim suo proprio, partim communi omnium hominum iure utuntur. nam quod quisque populus ipse sibi ius constituit, id ipsius proprium civitatis est vocaturque ius civile, quasi ius proprium ipsius civitatis: quod vero naturalis ratio inter omnes homines constituit, id apud omnes peraeque custoditur vocaturque ius gentium, quasi quo iure omnes gentes utuntur. ${ }^{24}$

Having established the theoretical debate in which these lines are inscribed, it is necessary to elaborate on it with further methodological precision. The specific references made in Mexico's case are due to the country's distinctive characteristics. Mexico, unlike other States in the region, has not experienced any military dictatorship. Even within its authoritarianism, elections were held periodically through electoral institutions and political rights were malfunctioning, which was combined with a full reform on human rights issues

21 Felice Battaglia, Introduzione, in Filosofi Tedeschi D’oggi 9 (Il Mulino 1967).

22 "El concepto de ius commune latinoamericano en derechos humanos: elementos para una agenda de investigación”, in Ius constitutionale... 212 ss; ID, Impacto e implicaciones..., cit., 310 ss.

23 D. 1.1 .9 (Gai., 1 inst.).

24 "The laws of every people governed by statutes and customs are partly peculiar to itself, partly common to all mankind. Those rules which a state enacts for its own members are peculiar to itself, and are called civil law: those rules prescribed by natural reason for all men are observed by all peoples alike, and are called the law of nations." The Institutes of Justinian, Title II, Paragraph 1. 
somewhat late for the subcontinent, the view of what will be expressed in the following pages. ${ }^{25}$

In this context, the analysis will focus on the right to vote, both actively and passively, in regional - inter-American - and national orders. Thereafter, it will be discussed from a theoretical perspective and the conception and functions of political rights in general from a normative perspective - from the prism of positive Mexican law-, to subsequently discuss the right to vote.

\section{Political Rights}

\section{A Conceptual Change: Prerogatives and Rights}

According to that which was pointed out at the beginning of this note regarding the crisis of the liberal State, universal suffrage was the trigger for the consolidation of the model of the mass party in the second half of the 20th century. This in itself results in a socialization of politics. Therefore, several fundamental questions on political rights will be analyzed from a theoretical perspective and with a specific emphasis on Mexican normative framework as a system that has undergone the transition in the public law schemes.

First, it must be said that political rights are fundamental rights. This affirmation perhaps might not be necessary in a historical context other than the Mexican one. So, what do we mean by fundamental rights? Among the doctrinaires of Legal Garantism, Luigi Ferrajoli defines them as follows:

All those subjective rights to which 'all' human beings are universally entitled by virtue of having the status of persons, or of citizens, or of persons capable of acting; understanding 'subjective right' as any positive expectation (of benefits) or negative expectation (not to suffer harm) ascribed to a subject by a legal rule; and 'status' as the condition of a subject for which provision is also made by a positive legal norm as a precondition of his suitability to hold entitlement to legal situations and/or be the author of the acts that are their exercise. ${ }^{26}$

Considering fundamental rights as a kind of subjective rights is generally accepted in theory, as in the case of Latin America, in which authors like Carlos Bernal Pulido add to what Ferrajoli calls positive and negative expectations, would be found in a legal situation of duties, attachments and non-competencies. ${ }^{27}$ In this sense, it is possible to see how the legal relation-

25 The constitutional reform that un-controversially integrated international human rights standards into the Mexican legal system took place in September 2011.

26 Luigi Ferrajoli, Derechos y garantías 37 (5th ed. 2006).

27 Carlos Bernal Pulido, Los derechos fundamentales en la Jurisprudencia del Tribunal Electoral del Poder Judicial de la Federación 20 (TEPJF 2009). It should be clari- 
ship between the authority and the individual is explained in classical terms: through supra-subordination in which the holder of the fundamental subjective right is the governed, and the obligated subjects are the State organs.

According to Ferrajoli, there are four types of fundamental rights, depending on the subject that acts as their owner/holder, namely: human rights, public rights, civil rights and political rights. For him, political rights are: “...those reserved only for citizens with capacity to act, such as the right to vote, passive suffrage, the right to access public office, and, in general, all the optional rights in which political autonomy is manifested and those that are based on representation and political democracy". ${ }^{28}$

In other definitions of the Latin American context, Sonia Picado describes political rights as "entitlements that, taken together, result in the broad exercise of political participation." 29 The point to be highlighted is the terminology of 'political participation', which, although it covers electoral issues, it goes further by including other aspects, such as the creation of public policies.

From the point of view given in this note, political rights have a broader connotation than being merely restricted to the electoral world. Although political participation certainly implies the exercise of the rights to vote and to be voted for, it also includes the possibility of directly influencing the performance of the governing bodies, under the premise of meeting the conditions of both nationality and citizenship.

As noted above, in Mexican legal experience, political rights have not always been considered fundamental rights. This is supported by the ambiguous references that, in this respect, the Mexican Constitution has made to these rights when they were conceived indiscriminately as prerogatives, rights and even obligations.

The original text of Article 35 of the Mexican Constitution made mention of political voting rights, in its active and passive forms, as well as to political association, as 'prerogatives', a term that led to diverse interpretations by the Supreme Court. Based on the first title of the Constitution, which called fundamental rights 'individual guarantees', political rights were excluded from that category because these rights were granted exclusively to citizens and not to men. This was corroborated by classifying these rights as prerogatives, as opposed to guarantees. ${ }^{30}$

fied that Bernal uses terms like rights, freedoms and competencies to refer to positive expectations, and immunities to refer to negative ones.

28 Ferrajoli, supra, at 37.

29 Derechos políticos como derechos humanos, in TRATADO DE DERECHO ELECTORAL COMPARADO DE AmÉrica Latina 48 ( 2nd ed. 2007).

30 Consequently, political rights were not protected by the amparo, see: Séptima Época, Pleno, Semanario Judicial de la Federación 71, primera parte, p. 21, tesis aislada. Derechos POLITICOS, AMPARO IMPROCEDENTE POR VIOLACION A. 
The Supreme Court of Justice of the Nation's argument even refused to consider political rights fundamental rights, based on an argument sedes materiae, on the constitutional text, since these rights were not included in the first twenty-nine articles. As to the dogmatic part, these rights were offered under the heading of 'individual guarantees', the nature of which should be considered different from fundamental rights. ${ }^{31}$

This notion of political rights in the interpretation of the Mexican constitutional court subsisted until the end of the $20^{\text {th }}$ century, when in the so-called Amparo Camacho' that distinction between political-electoral rights and the socalled individual guarantees was still upheld. ${ }^{32}$

At this point, the acceptance of international human rights manifested a potentially profound impact on the Mexican legal system as seen in Amparo Trial 743/2007. Although the complainant Jorge Castañeda did not obtain federal protection - due to an issue of origin of the amparo trial -, in its ruling the Mexican Court became a spokesperson for considering political rights fundamental rights. ${ }^{33}$

Castañeda's decision to continue with the case before the bodies established by the Pact of San José spurred the change of some institutions in Mexican electoral law, along with subsequent legal and constitutional reforms. ${ }^{34}$

Another way in which the Mexican Constitution alluded to political rights in its original wording was one of obligations, when considering that citizens have the duty of holding elected office, an issue that gave rise to the construction of 'mandatory voting' doctrine, especially about the implications of the very concept of fundamental rights, as well as the fact that the legitimacy of the political system must be sought by ways other than the obligatory nature of participation.

Meanwhile, the express acknowledgment of political rights as rights; that is, this term only begins to be used in 2011, in the article that provides for the suspension of rights before a state of emergency.

31 Amparo en revisión 5588/73. Derechos politicos, AMPARO IMPROCEDENTE POR VIOLACION A.

32 P. LXIII/99. Tesis Aislada. Reforma constitucional, Amparo contra su proceso de CREACIÓN. PROCEDE POR VIOLACIÓN A DERECHOS POLÍTICOS ASOCIADOS CON GARANTÍAS INDIVIDUALES.

33 See: Ferrer Mac Gregor, Eduardo y Silva García, Fernando, El caso Castañeda ante la Corte Interamericana de Derechos Humanos. La primera sentencia internacional condenatoria contra el Estado mexicano, México, Ed. Porrúa, 2009. For issues of thematic clarity, it is specified that in this case Mexico was found responsible for violating Jorge Castañeda's judicial guarantees, enshrined in Articles 8 and 25 of the American Convention on Human Rights (Pact of San José), and not his rights politicians (article 23 of the same international instrument).

34 Markedly, the possibility that the Electoral Court of the Federal Judicial Branch could carry out a widespread control of laws in the case submitted to its examination. 


\section{A Specific Reference to the Right to Vote}

Latin American doctrine has defended two conceptual positions regarding the right to vote, calling it, on the one hand, a "right of suffrage", a term that emphasizes a purely political connotation, ${ }^{35}$ and rejecting a distinction between the right to suffrage and the right to vote on the other hand. ${ }^{36}$

The position that rejects the distinction between the right to vote and the right to suffrage finds justification in the fact that it places the right to vote as a source of suffrage because if one speaks of the right to vote as a political right, the reference to said right is clear, one of active suffrage.

In this sense, Fix Fierro defines the right to vote as "...the power that the citizen has to express his will in favor of the candidates to hold positions of popular election of all kinds; that is, it allows him to act as a member of the body in charge of the designation." 37 The concept is fitting in terms of restricting the right to vote to the electoral procedures that emanate from the holders of popularly elected offices, which is highlighted on the fact that other definitions, such as Aragon's, ${ }^{38}$ the right to active suffrage includes any public consultation, which is confused, for example, with the figure of the referendum.

\section{A Specific Reference to the Right to Hold Public Office}

Mention should now be made to two issues that underlie the right to vote in its passive aspect that arise from Inter-American Court case law: the monopoly of candidacies by political parties and equal access to candidacies in the case of indigenous peoples.

Regarding political parties' monopoly of candidate registration, it was not until 2012 that Mexico presented this issue before the Inter-American Court of Human Rights, which, by applying the principle of proportionality, ruled that the exclusivity of candidate registration by political parties was valid when rendered as a suitable way to prop up the course and consolidation of a democracy as the primary objective of electoral reforms. ${ }^{39}$ The words of the Court are very eloquent to this regard:

Regarding whether the measure was adapted to achieving the legitimate objective sought, based on the above the Court finds that, in the instant case, the

35 Mario Fernández \& José Thompson, El voto obligatorio, in NOHLEN 256.

36 Manuel Aragón, Derecho de sufragio: principio y función, in NOHLEN 162. The position of Aragon is based on premises of privacy: shareholders have the right to vote in the assemblies, which is why it is better to call it 'suffrage', as a way to specify the right to vote in political matters.

37 Héctor Fix Fierro, Los derechos políticos de los meXicanos 45 (UNAM 2006).

38 Ibid. at 45

39 Castañeda Gutman v. Mexico, paragraph 199. 
exclusivity of nomination by political parties to elected office at the federal level is an appropriate measure to produce the legitimate result sought of organizing the electoral processes efficiently in order to hold genuine periodic elections, by universal and equal suffrage and by secret vote that guarantee the free expression of the will of the voters, as established by the American Convention. ${ }^{40}$

With this ruling, the regional body of jurisdiction in the field of human rights gave a vote of confidence to the representative democracy system, whose fundamental component is political parties, which obiter dictum, also constitute an expression of political rights, and specifically the right to association.

On the other hand, an additional issue that has captured the attention of the Inter-American Court is the egalitarian character of passive suffrage. In the case of Yatama v. Nicaragua, the Court determined that by banning participation in the Yapti Tasba Masraka Nunh Asla Takanka (Yatama) regional indigenous political party in municipal elections the Nicaraguan State acted in a discriminatory manner since the burden of participating had been imposed on various indigenous communities through forms of political organization that were not their own. It was pointed out that, although there is freedom of composition in the design of democratic institutions, what is compatible with the international framework on human rights is to open spaces for all persons, including those belonging to indigenous communities. The Inter-American Court put it this way:

207. States may establish minimum standards to regulate political participation, provided they are reasonable and in keeping with the principles of representative democracy. These standards should guarantee, among other matters, the holding of periodic free and fair elections based on universal, equal and secret suffrage, as an expression of the will of the voters, reflecting the sovereignty of the people, and bearing in mind, as established in Article 6 of the Inter-American Democratic Charter, that " $[\mathrm{p}]$ romoting and fostering diverse forms of participation strengthens democracy"; to this end, States may design norms to facilitate the participation of specific sectors of society, such as members of indigenous and ethnic communities.

\section{A Tentative Conclusion: Belonging to Multiple Normative Spaces and the Person's Centrality}

What has been said up to this point raises an interesting panorama. In the ius constitutionale commune space, the existence of different normative orders within national States makes their relationship with regional human rights law more complex, but the essence of the purpose remains intact: the protection of the individual.

In its first and ninth articles, the Inter-American Democratic Charter prescribes that the 'peoples' of America have a duty to promote democracy,

$40 \quad$ Ibid. at paragraph 203. 
while respecting cultural plurality at all times. This shows that the dominant concept in the application of the ius constitutionale commune is that of the maximum protection of the person.

Thus, in the inter-American human rights system, dignity mainly plays the role of limiting any interference, effect, restriction or damage to personal integrity, privacy and freedom. Therefore, there is a set of prohibitions - in matters of slavery or servitude; torture; cruel, inhuman and degrading treatment; as well as arbitrary or abusive interference with private life, family, home or correspondence - which the system expressly protects. ${ }^{41}$

The founding documents of the ius commune constitutionale inter-American states that: "All men are born free and equal, in dignity and in rights, and, being endowed by nature with reason and conscience, they should conduct themselves as brothers one to another. [...] Inasmuch as spiritual development is the supreme end of human existence and the highest expression thereof, it is the duty of man to serve that end with all his strength and resources."42

The legal expression of these ideas in the application of normative materials is found in the interpretative clauses, such as the pro persona principle, according to which the protection of inter-American human rights norms is not restricted to this express focus on human dignity. The pro persona clause in the inter-American system is expressed in the form of prohibitions, which can be classified into two groups.

First, an interpretation cannot limit or suppress any right contained in the convention itself or in State legal systems that is not valid.

Second, it is not possible to interpret a limitation or exclusion in the rights that: a) are inherent to a human being; b) derive from a democratic and representative form of government; c) come from "other international acts", or d) correspond to the effects of the American Declaration of the Rights and Duties of Man.

To preserve dignity, it is necessary to make an extensive interpretation of the applicable corpus, as well as the norms themselves, whether rules or principles, to be applied and incorporated into all the liberties embodied in the human rights system. Because of this, it is necessary to indicate how the pro persona clause in the American Convention is comprised.

Regarding the first point, in Advisory Opinion 1/82, the Peruvian State asked the Inter-American Court about the scope of the phrase "or of other treaties concerning the protection of human rights in the American states," contained in Article 64 of the Pact of San Jose. The Court considered that the phrase composed of the expression "other treaties" referred to any treaty in which one of the signatories was also a party to the American Convention. ${ }^{43}$ In this way, the corpus applicable to a person is extended in that, in the

41 American Convention on Human Rights art. 5, 6, 11, Nov. 22, 1969.

42 Preamble to the American Declaration of the Rights and Duties of Man, approved at the Ninth International Conference of American States, Bogota, Colombia, 1948.

43 Of course, the effects would be produced only in the States that were part of the inter- 
case of human rights norms, such treaties are a source of rights protected by the Inter-American Court.

With regard to the second point, perhaps the most relevant criterion is found in Advisory Opinion 5/85, since it broadens the meaning of the provisions of article 29 of the Pact of San Jose, since, as has been pointed out, it conceives the pro persona principle as a rule that comprises a series of prohibitions on any interpretation that leads to the limitation or restriction of rights. However, in this case, the Court overruled the text of the rule, extending its meaning and establishing that the pro persona interpretation implies that:

[...] if in the same situation both the American Convention and another international treaty are applicable, the rule most favorable to the individual must prevail. Considering that the Convention itself establishes that its provisions should not have a restrictive effect on the enjoyment of rights guaranteed in other international instruments, it makes even less sense to invoke restrictions contained in those other international instruments, but which are not found in the Convention, to limit the exercise of the rights and freedoms that the latter recognizes. ${ }^{44}$

In this way, yet another aspect of the interpretation clause in question becomes valid: that of selecting the most favorable provision and not simply that regarding the prohibition of restrictive interpretations.

In view of the above, ius commune can also be understood as a political and legal project that is legitimized through the concept of inclusion, which conveys another echo of Roman thought and culture, bearing in mind the legal sources in which Rome is referred to as the common homeland. ${ }^{45}$

If one of the above-mentioned implications is the achievement of equitable national societies, the ius commune is presented as the ideal instrument to accomplish this project, setting aside the formal consideration that corresponds to the preservation of the hierarchy of a normative system, according to the terms of Kelsenian thought as explained above, or of Weber's theses in which objective rationality and the modern State are compatible, and in whose context "[j] uridical formalism enables the legal system to operate like a technically rational machine. Thus it guarantees to individuals and groups within the system a relative maximum of freedom, and greatly increases for them the possibility of predicting the legal consequences of their actions."46

American system: the dimension is important, by virtue of the multilateral treaties in which countries not belonging to the region can participate.

44 Advisory opinion 5/85.

45 Emblematic: D. 50.1.33 (Mod., l. sing. de manum.): Roma communis nostra patria est [Rome is our common native country.]; and see: D. 27.1.6.11 (Mod., 2 excus., in Greek); D. 48.22.18.pr.

46 Max Weber, Economía y sociedad 146 (Fondo de Cultura Económica 1944). 
A 'technically rational machine' with ample space for 'predicting the legal consequences'; that is, the relinquishment of casuistic, episodic, arbitrary systems through the institutionalization of legal-rational procedures. In fact, for Weber and those who follow his doctrine, the historical process of modernization is equivalent to the rationalization and institutionalization of power, which happens when power systems/structures that are unable to act in a continuous, regulated and objective manner are overcome/ended. In modernity, we can affirm the existence of a public subject, the State, which has seized all the material means suitable for achieving its ends. This reflects the real transformation that has taken place on a historical level because it is not mainly due to the replacement of various political subjects for the reality, but more so due to the advent of an especially qualified subject; that is, through an institutionalized act.

In Grossi's words, "the State is a notion that possesses a specific historical niche $[\ldots]$ the time territory that corresponds to this subject is undoubtedly the modern one, which represents perhaps the most striking and undoubtedly also the most expressive outcome." ${ }^{47}$ Naturally, the incorporation of the material into its sphere of power is the result and a factor of the appropriation of the administrative activity of individual behaviors and economic goods, canceling out the previous associative-subjective context, and placing the institutional dimension and bypassing the centrality of the person as its central axis.

By taking a certain distance from the enshrined explanations of the doctrine on the modern State, inter-American law draws on concepts that justify the adherence to regional human rights regimes, namely supra-Statehood, multilateralism, voluntariness, collective hegemony, not only in terms of legitimacy, but also of practical convenience. ${ }^{48}$

In other words, in this new model, many of the concepts of modernity regarding State monopoly of the public power are overcome, and instead turns to a longstanding tradition of the Roman matrix system by reshaping the need for multilevel cooperation within the context of the centrality of the human person as its cardinal element and center of its entire classical legal thought. ${ }^{49}$

47 Paolo Grossi, Un derecho sin Estado. La noción de autonomía como fundamento de la constitución jurídica medieval, in ANUARIO MEXICANO DE HISTORIA DEL DERECHO 167-178 (1997), nOw in Derecho, sociedad, Estado, Mexico, El Colegio de Michoacán - Escuela Libre de Derecho Universidad Michoacana de San Nicolás de Hidalgo 19 (2004).

48 ARmin Von Bogdandy, La protección de los vulnerables: un ejemplo de gobernanza posnacional, in HaCia un NUEVo DERECHO PÚblico. Estudios DE DERECHO PÚBLICO COMPARADO, SUPRANACIONAL E INTERNACIONAL 341 (UNAM 2012)

49 D. 1.5.2 (Hermog., 1 iuris epit.): ... Hominum causa omne ius constitutum est. [Every law has been created for the sake of men.] 